\title{
Phospholipid composition and resistance to vitrification of in vivo blastocyst of a Brazilian naturalized porcine breed
}

\author{
[Composição de fosfolipídios e resistência à vitrificação de blastocistos produzidos in vivo \\ de uma raça de suíno naturalizada brasileira] \\ J.F.W. Sprícigo ${ }^{1,2 *}$, L.O. Leme $^{1}$, A.L. Guimarães ${ }^{3}$, J.C. Oliveira Neto4, P.C.P. Silva ${ }^{3}$, \\ N.H. Moreira ${ }^{3}$, I. Pivato ${ }^{3}$, B.D.M. Silva ${ }^{1}$, A.F. Ramos ${ }^{1}$, M.A.N. Dode ${ }^{1}$

\footnotetext{
${ }^{1}$ Embrapa Recursos Genéticos e Biotecnologia - Brasília, DF

${ }^{2}$ University of Guelph, Animal Science- Guelph, ON, Canada

${ }^{3}$ Universidade de Brasília - Brasília, DF

${ }^{4}$ Universidade Federal do Espírito Santo - Alegre, ES
}

J.F.W. Sprícigo

https://orcid.org/0000-0002-5507-3923 L.O. Leme

https://orcid.org/0000-0003-4818-1202 A.L. Guimarães

https://orcid.org/0000-0002-6533-2490 Oliveira Neto https://orcid-org/0000-0003-0369-9649 P.C.P. Silva

https://orcid.org/0000-0002-1641-7316 N.H. Moreira

https://orcid.org/0000-0002-3639-7500 I. Pivato

h.D.M. Silva

B.D.M. Silva
https://orcid.org/0000-0003-2206-2600 htps://orcid

https://orcid.org/0000-0002-9668-8529

M.A.N. Dode
https://orcid.org/0000-0002-1096-0457

\begin{abstract}
Piau porcine blastocysts were submitted to MALDI-TOF to identify the main phospholipids (PL). After that, in vivo blastocysts (D6) were vitrified $(n=52)$, non-vitrified were used as control $(n=42)$. After warming, blastocysts were in vitro cultured to assess re-expansion and hatching at 24 and 48 hours. Finally, at 48 hours, hatched blastocysts were submitted to RT-qPCR searching for BCL2A1, BAK, BAX and CASP3 genes. For MALDI-TOF, the ion intensity was expressed in arbitrary units. Blastocyst development was compared by Qui-square $(\mathrm{P}<0.05)$. Among the most representative PL was the phosphatidylcholine $[\mathrm{PC}(32: 0)+\mathrm{H}]+$; $[\mathrm{PC}(34: 1)+\mathrm{H}]+$ and $[\mathrm{PC}(36: 4)+\mathrm{H}]+$. Beyond the PL, MALDI revealed some triglycerides (TG), including PPL (50:2) + Na+, PPO (50:1) + Na+, PLO (52:3) + Na+ and POO $(52: 2)+\mathrm{Na}$. Re-expansion did not differ $(\mathrm{P}>0.05)$ between fresh or vitrified blastocysts at 24 $(33.3 \% ; 32.7 \%)$ or 48 hours $(2.4 \% ; 13.5 \%)$. Hatching rates were higher $(\mathrm{P}<0.05)$ for fresh compared to vitrified at $24(66.7 \% ; 15.4 \%)$ and 48 hours $(97.6 \% ; 36.0 \%)$. BAX was overexpressed $(\mathrm{P}<0.05)$ after vitrification. In conclusion, Piau blastocysts can be cryopreserved by Cryotop. This study also demonstrated that the apoptotic pathway may be responsible for the low efficiency of porcine embryo cryopreservation.
\end{abstract}

Keywords: pig, embryo, cryopreservation, lipids, apoptosis

\section{RESUMO}

Blastocistos de suínos foram submetidos ao MALDI-TOF para se identificarem os principais fosfolipídios $(P L)$. Depois, parte destes embrióes (D6) foram vitrificados $(n=52)$, ou permaneceram frescos (grupo controle, $n=42$ ). Após o aquecimento, os blastocistos foram cultivados in vitro para se avaliar a reexpansão e a eclosão (BE) às 24 e 48 horas. Finalmente, às 48 horas, os BE foram submetidos ao RT-qPCR em busca dos genes BCL2A1, BAK, BAX e CASP3. No MALDI-TOF, a intensidade do íon foi expressa em unidades arbitrárias. $O$ desenvolvimento embrionário foi comparado por qui-quadrado $(P<0,05)$. Entre os $P L$ mais representativos estavam as fosfatidilcolinas $[P C(32: 0)+H]+;[P C(34: 1)+H]+e[P C(36: 4)+H]+$. Além do PL, o MALDI revelou alguns triglicerídeos (TG), incluindo PPL (50: 2) + Na +, PPO (50: 1) + Na +, PLO (52: 3) + $N a+$ e POO (52: 2) + Na. A reexpansão não diferiu $(P>0,05)$ entre blastocistos frescos ou vitrificados às 24 $(33,3 \%, 32,7 \%)$ e 48 horas $(2,4 \%, 13,5 \%)$. As taxas de eclosão foram maiores $(P<0,05)$ para o grupo fresco comparado ao vitrificado às 24 (66,7\% x 15,4\%) e 48 horas (97,6\% x 36,0\%). O BAX estava mais expresso $(P<0,05)$ após a vitrificação. Concluindo, os blastocistos Piau podem ser criopreservados por Cryotop. Este estudo também demonstrou que a via apoptótica pode ser responsável pela baixa eficiência da criopreservação de embriões suínos.

Palavras-chave: suínos, embrião, criopreservação, lipídios apoptose

Recebido em 29 de agosto de 2017

Aceito em 20 de novembro de 2018

*Autor para correspondência (corresponding author)

E-mail: josespricigo_vet@hotmail.com 


\section{INTRODUCTION}

The pig industry is mainly based on high technology and intensive production systems using breeds with high genetic standards that are specialized for meat production (Davoli and Braglia, 2007; Fao, 2009; Gilbert et al., 2015). Naturalized pig species are known as animals that directly descend from those brought to South America by the colonizers between the XVII and XIX centuries. Those animals adapted to the local conditions, such as the climate and topography. These naturalized pigs have been selected in the last centuries, and they have guaranteed the sustainability of many Brazilian families. More recently, in the last five or six decades, naturalized pigs have been gradually replaced by commercial breeds that mainly originated from Europe (França, 1991).

The naturalized pig breeds of Brazil are characterized by their rusticity, resistance to diseases, and low requirements for management and feeding, as well as their high adaptability to Brazilian tropical conditions. Of those naturalized pig breeds, the Piau is the most notorious. This breed was used in some programs of genetic improvement because the breed has been used for dual purpose meat and fat (França, 1991). Of note, animals from the Piau breed have some morphological characteristics similar to commercial pig breeds. Recently, the product of crossbreeding Landrace, Large Withe and some of the national breeds has been announced by the Brazilian Agricultural Research Corporation (Embrapa-Swine and Poultry, Concórdia- Brazil) as its last maternal swine lineage. Therefore, the conservation of that germplasm into a gene bank is important for several reasons, such as genetic uniqueness, traits of economic importance, adaptation to a specific environment and cultural or historical value.

In the last decades, different groups around the world have being working on protocols and techniques to improve embryo cryopreservation in different species (Garcia-Garcia et al., 2005; Oliveira Leme et al., 2016; Diaz et al., 2016). Unfortunately, the swine embryo has been more resistant to cryopreservation than the embryos of many other mammals, especially due to their peculiar high lipid content and lipid composition (Castillo-Martin et al., 2014; Dunning et al., 2014). In fact, the first significant advance toward the successful cryopreservation of swine embryos was based on the observation that they are very sensitive to hypothermic conditions and that the removal of intracellular lipids (delipation) alleviates this sensitivity (Cuello et al., 2004; Anchamparuthy et al., 2010). Another important factor that affects the success of cryopreservation is the methodology. Currently, there are two possible approaches for storing gametes and embryos, the slow freezing process and the vitrification process (Saragusty and Arav, 2011). Although it is a practical application, the slow freezing process allows for the formation of water ice crystals (Saragusty and Arav, 2011) and the production of high quantities of $\mathrm{O}_{2}$ peroxides (Dunning et al., 2014). On the other hand, the vitrification process does not result in ice crystal formation and it has reduced oxidative injuries (Vajta et al., 1998). It is important to note that regardless of the methodology used, gametes and embryos are not only affected in the morphological aspect, they are affected in terms of the transcription process and mRNA content, which can reflect on important developmental pathways (Turathum $e t$ al., 2010; Castillo-Martin et al., 2015).

Although substantial effort has been spent, cryopreservation of swine embryos remains a challenge due to the poor results observed after warming, with hatching rates of approximately 40-50\% (Nagashima et al., 1992; Nagashima et al., 1995; Ushijima et al., 2004; Sakagami et al., 2016). In addition to the already mentioned characteristics, the membrane fatty acid composition of embryos and gametes (Spricigo et al., 2015) has been described as one possible cause of membrane permeability during freezing and warming (Sudano et al., 2012). Therefore, membrane composition could determine the resistance of mammalian embryos during vitrification and warming.

The main objective of the present study was to characterize embryos from the Piau breed by evaluating the plasma membrane fatty acid composition and evaluating their behavior regarding re-expansion rates, hatching rates and gene expression after vitrification and warming.

\section{MATERIAL AND METHODS}

Unless otherwise indicated, chemicals were purchased from Sigma (St. Louis, MO, USA). 
Cryotop devices were acquired from DibimedBiomedical Supply (S.L. Valencia, Spain).

All experiments were conducted according to Brazilian laws. The project was approved by the Committee for Ethics in Animal Use (CEUA) of the Institute of Biological Sciences of the University of Brasilia under protocol number UnBDOC-150682 / 2012.

Briefly, Piau $(n=58)$ females had their estrus observed and were exposed to males to naturally mate. Six days after mating (D6), the animals were taken to the operating room for embryo collection. The sows were tranquilized with azaperone $(2 \mathrm{mg} / \mathrm{kg} / \mathrm{IM})$ and anaesthetized with ketamine $(15 \mathrm{mg} / \mathrm{kg} / \mathrm{IV})$. They were placed on a surgical table in a Trendelenburg position. The uterine horns were exposed by means of a midventral incision, and the ovaries were examined to measure ovulation. A Foley $\mathrm{n}^{\circ} 14$ catheter, connected to a Petri-dish, was inserted $25 \mathrm{~cm}$ from the utero-tubal junction (UTJ). A $n^{\circ} 16$ intravenous catheter was inserted next to the UTJ through which $60 \mathrm{~mL}$ of $\mathrm{PBS}$ at $37^{\circ} \mathrm{C}$ was introduced. The uterine horns were massaged to assist in recovering the embryos. After total recovery of the PBS, the procedure was repeated for the other horn.

The search and selection occurred under a stereomicroscope (Nikon- SMZ 650), and the recovered structures were classified according to International Embryos Technology Society (IETS) manual (Robertson I, 1998). For the experiments, only blastocysts (BL) and expanded blastocysts (BX) graded as I or II were used (n= 110).

Expanded Piau blastocysts $(\mathrm{n}=8)$ were washed five times in methanol / pure water 1:1 (v/v) drops and stored in the same solution in micro centrifuge tubes at $-80^{\circ} \mathrm{C}$ until analysis. After thawing, the blastocysts were individually allocated into a MALDI target well in a 96-well steel plate. The blastocysts were dried at room temperature. Prior to analysis, $1 \mu \mathrm{l}$ of 2,5 dihydroxybenzoic acid (0.125M, DHB) diluted in pure methanol was deposited in each well to cover the oocytes and allow for crystallization. Blastocysts were again allowed to dry at room temperature.
The spectra obtained with mass spectrometry MALDI-TOF were acquired in the positive mode by reflected mass spectrometer Auto Flex Speed MALDI-TOF/TOF (Bruker Daltonics, Bremen, Germany). Data were acquired at a mass range from $700-1200 \mathrm{~m} / \mathrm{z}$ with 1500 laser shots in different blastocyst regions. The laser was applied until the time when signs had disappeared in the region of interest due to sample desorption. The laser intensity was standardized at $40 \%$ for the spectrum acquisition in all samples. Spectra were centered and aligned using mMass 5.5.0 software (Niedermeyer and Strohalm, 2012). The most intense ions upon detection of peaks corresponding to isotopic distributions were considered to identify a starting point corresponding to the lipid ions.

Embryo vitrification was performed as previously described (Oliveira Leme et al., 2016) with slight modifications. The holding medium (HM), which was used to handle embryos during vitrification and warming, consisted of HEPESbuffered TCM-199 (Gibco) supplemented with $20 \%$ fetal calf serum. For vitrification, the embryos were first exposed to an equilibrium solution consisting of $7.5 \%$ ethylene glycol and 7.5\% DMSO for 9 to 15 minutes. Embryos were transferred to a vitrification solution consisting of $15 \%$ ethylene glycol, $15 \%$ DMSO, and $0.5 \mathrm{M}$ sucrose in HM. Next, the embryos were placed in a Cryotop device in sets of 3 to 5 under a stereomicroscope (Nikon- SMZ 650), and the device was immediately submerged into liquid nitrogen. The time between the second solution exposition and $\mathrm{N}_{2}$ was fixed between 45 and 90 seconds. Warming was performed immediately after vitrification by immersing the Cryotop end for 1 minute into a drop of HM that was prewarmed to $37^{\circ} \mathrm{C}$ and supplemented with $1 \mathrm{M}$ sucrose. The embryos were transferred to HM supplemented with $0.5 \mathrm{M}$ sucrose for 3 minutes and then to the original HM for another 5 minutes.

After the warming period, the embryos from both groups were cultured in $\mathrm{SOF}$ medium at $38.5^{\circ} \mathrm{C}$ and $5 \% \quad \mathrm{CO}_{2}$ in air. Embryos were morphologically evaluated at 24 and 48 hours during culture with a stereomicroscope (NikonSMZ 650) to determine developmental progression. Blastocysts that reorganized during culture and displayed a normal or thinning pellucid zone, with an excellent or good 
appearance, were considered viable. The in vitro survival rate was defined as the ratio of viable embryos after culture to the total number of cultured embryos. Viable embryos were also divided, expanded and hatched. The in vitro expansion and hatching rates were defined as the number of expanded or hatched embryos to the total number of cultured embryos for both the fresh and vitrified groups.

Gene expression was performed after 48 hours of in vitro culture, and only hatched blastocysts were used. For each experimental group, the blastocysts were washed 4 times in PBS that was free of calcium and magnesium; afterwards, they were stored in microtubes with RNAlater at $20^{\circ} \mathrm{C}$ until RNA extraction.

Three pools of 6 embryos in each group were evaluated. For gene expression analysis, the following five apoptosis-related genes were selected: BCL2 related protein A1 (BCL2L1); BCL2 antagonist/killer 1 (BAK); BCL2 associated $X$, apoptosis regulator (BAX) and caspase 3, apoptosis-related cysteine peptidase (CASP3). The levels of expression of two housekeeping genes, glyceraldehyde-3phosphate dehydrogenase (GAPDH) and $\beta$-actin (ACTB) were subjected to GeNorm software (Vandesompele et al., 2002), which indicated ACTB is the most stable gene. This gene was used as a reference for data normalization.
Total RNA was isolated using the RNeasy Plus Micro Kit (Qiagen ${ }^{2}$, Hilden, Germany) according to the manufacturer's instructions (with minor modifications). The isolated total RNA was used for cDNA synthesis, which was performed using the First-Strand cDNA Synthesis Kit (Invitrogen) - SuperScript ${ }^{\circledR}$ III (200U/uL) and oligo(dT) primer $(0.5 \mathrm{ug} / \mathrm{uL})$ at a final volume of $40 \mu \mathrm{L}$. Reactions were performed at $65^{\circ} \mathrm{C}$ for 5 minutes and $50^{\circ} \mathrm{C}$ for 50 minutes, which was followed by inactivation of the enzyme at $85^{\circ} \mathrm{C}$ for 5 minutes. The qPCR analysis was performed using a Fast SYBR Green Master Mix (Applied Biosystems). The reactions were optimized to provide maximum amplification efficiency for each gene (90-110\%) by calculations using standard curves related to program 7500-2.0.3 (Applied Biosystems, USA). Each sample was analyzed in triplicate, and the specificity of each PCR product was determined by analysis of the melting curve. The reactions were performed in a final volume of $25 \mathrm{uL}$ using cDNA corresponding to 0.33 of an embryo. The conditions of PCR cycles were $95^{\circ} \mathrm{C}$ for 5 minutes, which was followed by 50 cycles of denaturation at $95^{\circ} \mathrm{C}$ for 10 seconds and annealing at $60^{\circ} \mathrm{C}$ for 30 seconds. The primer name, sequence and concentration; amplicon size; and annealing temperature of each gene are listed in Table 1.

Table 1. Primers used in this study to amplify gene fragments for real time RT-qPCR

\begin{tabular}{|c|c|c|c|}
\hline Gene & Primer sequence & $\begin{array}{l}\text { Amplicon } \\
\text { size (bp) }\end{array}$ & $\begin{array}{l}\text { Anneling Temperature } \\
\left(\left({ }^{\circ} \mathrm{C}\right)\right.\end{array}$ \\
\hline BCL2L1 & $\begin{array}{l}\text { (F) AGACAAGGAGATGCAGGTATTG } \\
\text { (R) CTCAGCTGCTGCATTGTTTC }\end{array}$ & 142 & $60{ }^{\circ} \mathrm{C}$ \\
\hline BAK & $\begin{array}{l}\text { (F) ATGACATCAACCGGCGATAC } \\
\text { (R) GTTGATGCCACTCTCGAACA }\end{array}$ & 125 & $60^{\circ} \mathrm{C}$ \\
\hline BAX & $\begin{array}{l}\text { (F) AGTAACATGGAGCTGCAGAG } \\
\text { (R) GCACCAGTTTACTGGCAAAG }\end{array}$ & 151 & $60^{\circ} \mathrm{C}$ \\
\hline CASP3 & $\begin{array}{l}\text { (F) CAGTTGAGGCAGACTTCTTGTA } \\
\text { (R) TCGGTTAACCCGAGTAAGAATG }\end{array}$ & 161 & $60{ }^{\circ} \mathrm{C}$ \\
\hline ACTB & $\begin{array}{l}\text { (F) GACCACCTTCAACTCGATCAT } \\
\text { (R) GATCTCCTTCTGCATCCTGTC }\end{array}$ & 124 & $60{ }^{\circ} \mathrm{C}$ \\
\hline GAPDH & $\begin{array}{l}\text { (F) GTCTGGAGAAACCTGCCAAATA } \\
\text { (R) CCCAGCATCAAAGGTAGAAGAG }\end{array}$ & 152 & $60{ }^{\circ} \mathrm{C}$ \\
\hline
\end{tabular}

Abbreviations: $F$, forward; $R$, reverse

To determine the phospholipid species phosphatidylcholines and sphingomyelins (PC and $\mathrm{SM}), \mathrm{m} / \mathrm{z}$ values were obtained and compared to those recently described in the literature (Ferreira et al., 2010; Sudano et al., 2012). An online database (www.lipidmaps.org) was also used to assist in lipid determination. To evaluate blastocyst development during in vitro 
culture, data were analyzed with the Chi-square test at a 5\% significance level. The relative expression of each gene was calculated using the $\Delta \Delta \mathrm{Ct}$ method with efficiency correction using the Pfaffl method (Pfaffl, 2001).

The objective of this experiment was to characterize the Piau blastocyst regarding the fatty acid composition on the plasma membrane. That information is important to better understand blastocyst performance when facing the stress of vitrification. After recovery and selection, expanded Piau expanded blastocysts $(n=8)$ were used to evaluate the phospholipids and fatty acids presents on the plasma membrane through MALDI-TOF mass spectrometry.

This study focused on evaluating the Piau embryo response to vitrification by Cryotop. For vitrification, only fresh embryos at $\mathrm{Bl}$ and $\mathrm{Bx}$ stages, grades I and II (Robertson I, 1998) were used. Embryos were distributed into the control group (control) - not cryopreserved and vitrified group (vitri). After the warming period, the embryos from both groups (control and vitri) were cultured in SOF medium (Holm et al., 1999 ) at $38.5^{\circ} \mathrm{C}$ and $5 \% \mathrm{CO}_{2}$ in air. At 24 and 48 hours of culture, the re-expansion and hatching rates were evaluated. Embryos that had reexpanded and hatched at those time points were considered viable, and the degenerated embryos were considered non-viable (Figure 1). Fresh and vitrified Piau hatched blastocysts after 48 hours of culture were used for gene expression analyses. The genes were involved in the apoptosis process and quantified by qPCR.

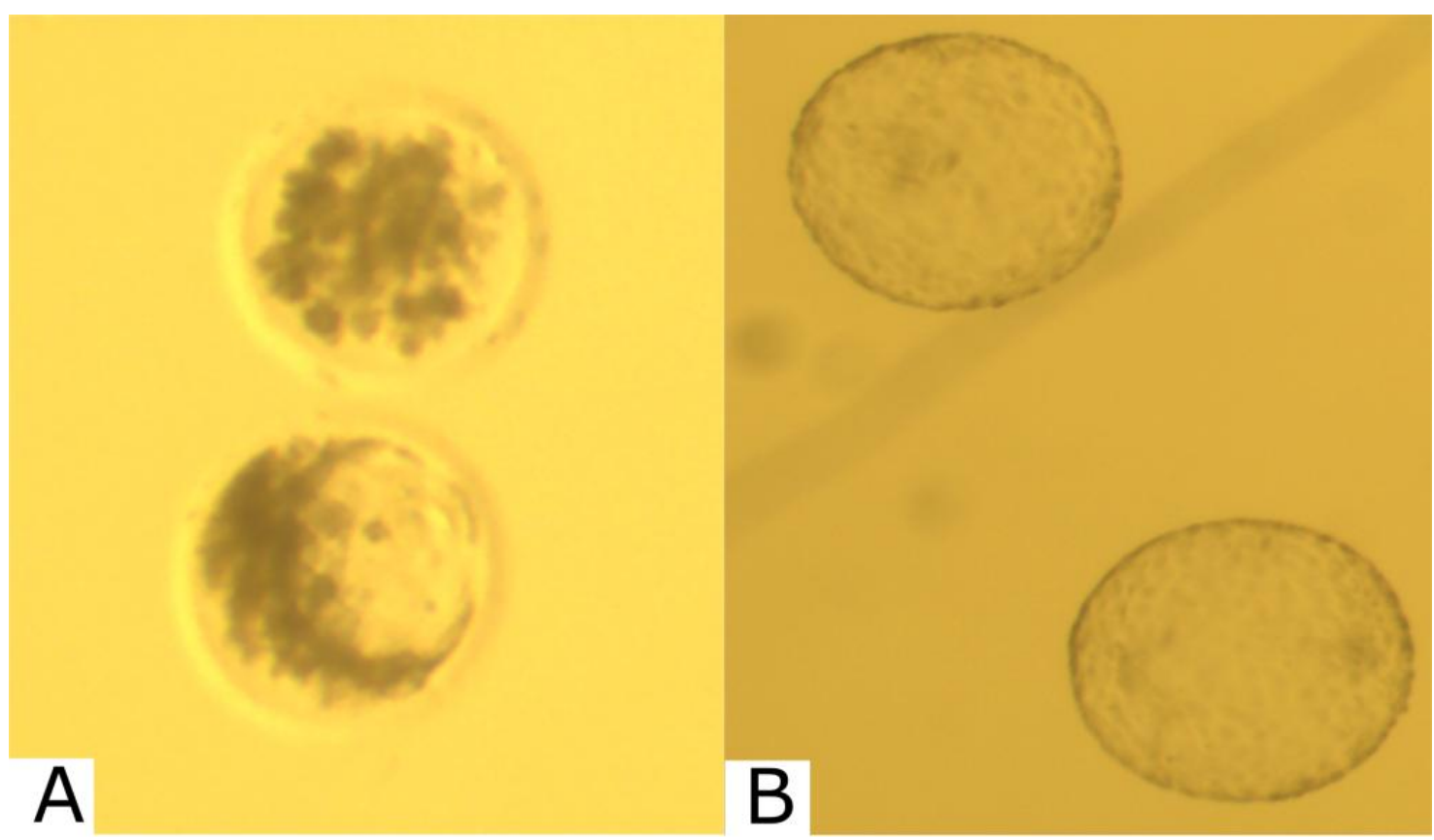

Figure 1. Representative images of in vivo produced Piau embryos that were in vitro cultured for 48 hours after vitrification and warming. Degenerated structures in $4 \mathrm{X}$ magnitude (A) and hatched blastocysts in $2 \mathrm{X}$ magnitude (B). The images were acquired in a stereomicroscope (Nikon- SMZ 650).

\section{RESULTS}

MALDI-TOF analyses of Piau $(n=8)$ Bx showed the presence of 16 lipids. Among the phospholipids, phosphatidylcholine $[\mathrm{PC}(32: 0)+$ $\mathrm{H}]+,[\mathrm{PC}(34: 1)+\mathrm{H}]+$ and $[\mathrm{PC}(36: 4)+\mathrm{H}]+$, represented by $734.5,760.5$ and $782.5 \mathrm{~m} / \mathrm{z}$ ions, had the highest intensity. Some triglycerides stored in the cytoplasm were also detected, including PPL (50:2) + Na+, PPO (50:1) + Na+, PLO (52:3) + Na+ and POO (52:2) + Na+, which were represented by $853.5,855.7,879.7$ and $881.6 \mathrm{~m} / \mathrm{z}$ ions (Figure 2).

According to the presented data in Table 2, the viability of fresh blastocysts was not affected by in vitro culture because the same viability $(\mathrm{P}>$ 0.05 ) was recorded at 24 or 48 hours of culture. 
In contrast, vitrified and warmed blastocysts had lower $(\mathrm{P}<0.05)$ viability rates than the control embryos at 24 and 48 hours. Viability was considered the ratio between the sum of reexpansion and hatching embryos over all cultured blastocysts. When the two parameters were individually examined, it was noted that at 24 or 48 hours, the re-expansion rate was similar (P> 0.05) between fresh and vitrified embryos. However, the hatched rates were drastically different $(\mathrm{P}<0.05)$ between groups (Table 2$)$.

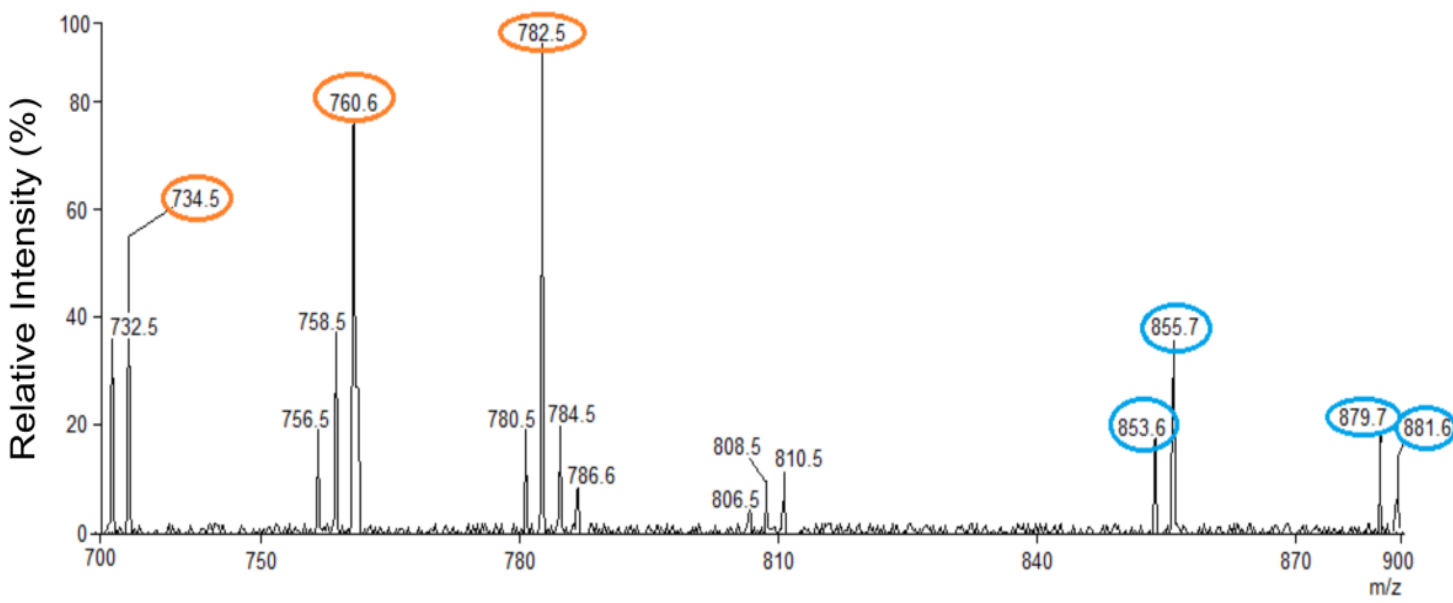

Figure 2. MALDI-TOF representative spectrum acquired in the positive ion mode for single and intact Piau blastocyst expansion $(n=8)$. Representation of most frequently observed ions: PHOSPHOLIPIDS (red circles)- phosphatidylcholine $[\mathrm{PC}(32: 0)+\mathrm{H}]+,[\mathrm{PC}(34: 1)+\mathrm{H}]+$ and $[\mathrm{PC}(36: 4)+\mathrm{H}]+$, which are represented by $734.5,760.5$ and $782.5 \mathrm{~m} / \mathrm{z}$ ions, respectively, and showed high intensity. Some TRIGLYCERIDES (blue circles) were also found: PPL (50:2) + Na+, PPO (50:1) + Na+, PLO (52:3) + $\mathrm{Na}+$ and $\mathrm{POO}(52: 2)+\mathrm{Na}+$, which are represented by $853.5,855.7,879.7$ and $881.6 \mathrm{~m} / \mathrm{z}$ ions, respectively.

Among the analyzed genes, only BAX had differential expression between the groups; it group $(\mathrm{P}=0.04)$ than in fresh counterparts was more abundantly expressed in the vitrified (Figure 3).

Table 2. Developmental status after 24 and 48 hours of in vitro culture of fresh or vitrified and warmed in vivo blastocysts ( $\mathrm{Bl}$ and $\mathrm{Bx}$ ) collected from the Piau porcine breed

\begin{tabular}{|c|c|c|c|c|c|c|c|}
\hline \multirow[b]{2}{*}{$\begin{array}{l}\text { Fresh } \\
\text { or Vitri }\end{array}$} & \multirow[b]{2}{*}{$\begin{array}{c}\text { Embryo } \\
\text { s N }\end{array}$} & \multicolumn{3}{|c|}{24 hours } & \multicolumn{3}{|c|}{48 hours } \\
\hline & & $\begin{array}{l}\text { Viable } \\
\text { n (\%) }\end{array}$ & $\begin{array}{c}\text { Re-expanded } \\
\text { n (\%) }\end{array}$ & $\begin{array}{l}\text { Hatched } \\
\mathrm{n}(\%)\end{array}$ & $\begin{array}{l}\text { Viable } \\
\mathrm{n}(\%)\end{array}$ & $\begin{array}{c}\text { Re-expanded } \\
\text { n (\%) }\end{array}$ & $\begin{array}{c}\text { Hatched } \\
\text { n (\%) }\end{array}$ \\
\hline Fresh & 42 & $42(100.0)^{\mathrm{a}}$ & $14(33.3)^{\mathrm{a}}$ & $28(66.7)^{\mathrm{a}}$ & $42(100.0)^{\mathrm{a}}$ & $1(2.4)^{\mathrm{a}}$ & $41(97.6)^{a}$ \\
\hline Vitri & 52 & $25(48.1)^{b}$ & $17(32.7)^{\mathrm{a}}$ & $8(15.4)^{b}$ & $25(48.1)^{\mathrm{b}}$ & $7(13.5)^{\mathrm{a}}$ & $18(36.0)^{b}$ \\
\hline
\end{tabular}

${ }^{-}{ }^{a b}$ Different superscripts within columns indicate significant differences between treatments, according $X^{2-}$ test $(\mathrm{P}<0.05)$. 

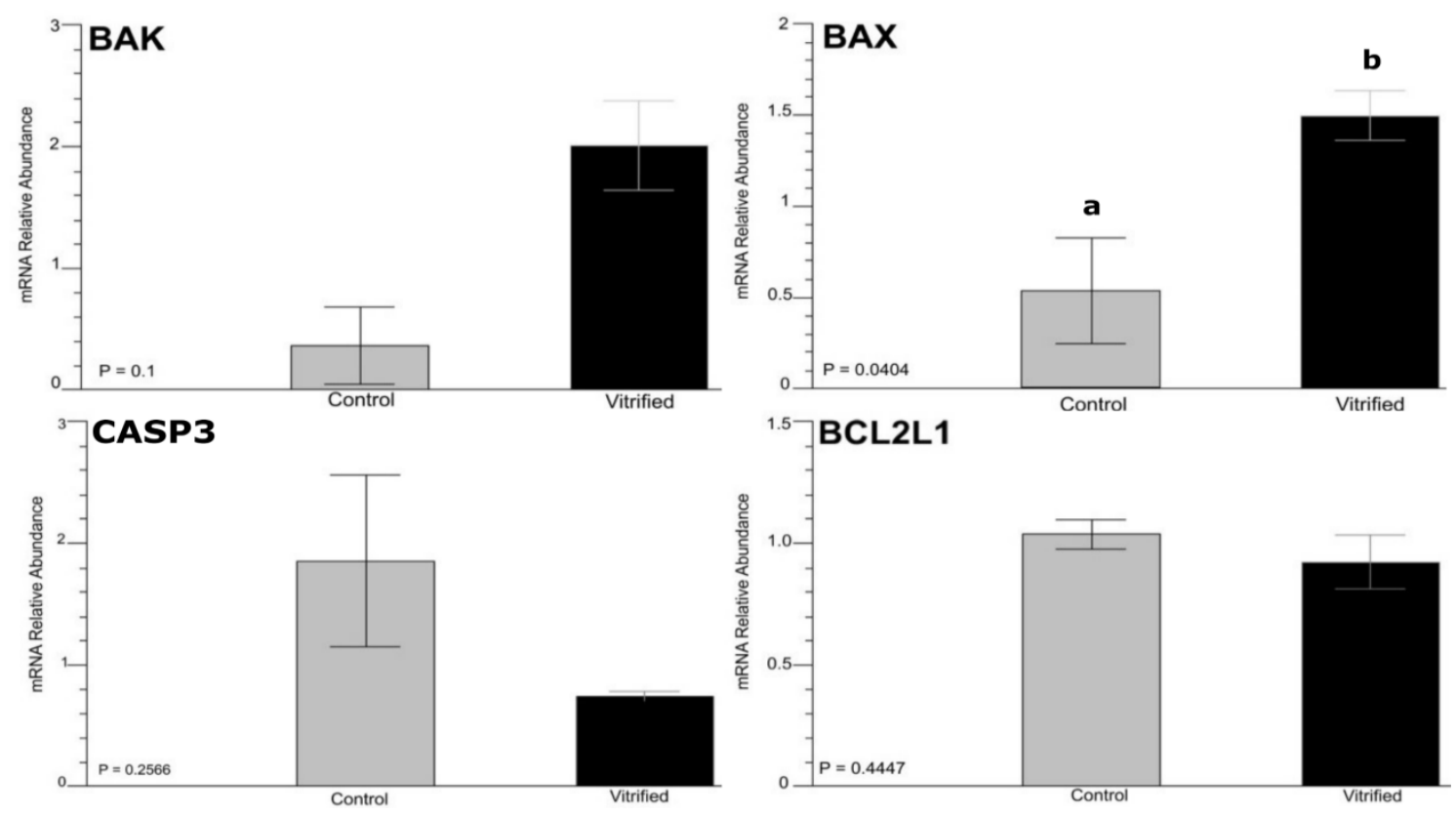

Figure 3. Transcript levels of BAK, BAX, CASP3 and BCL2L1 analyzed by RT-qPCR in hatched Piau blastocysts that were in vitro cultured for 48 hours from the non-cryopreserved group (control) and from the vitrified and warmed group (vitrified). The data (mean \pm SEM) are expressed relative to ACTB using the $\Delta \Delta \mathrm{Ct}$ method, and the analysis was performed in triplicate. ${ }^{\mathrm{a}, \mathrm{b}}$ Different letters in the bars indicate statistically significant differences in gene expression $(\mathrm{P}<0.05)$.

\section{DISCUSSION}

Currently, Piau is the most numerous porcine breed that has locally adapted to Brazilian conditions (Sollero et al., 2009). However, as for other national breeds, it has been gradually replaced by commercial breeds, increasing the chances of becoming extinct. Therefore, there is a demand for the preservation of that genetic material not only for conservation programs but also to preserve the traits of adaptation to a specific environment, which can be interesting for crossbreed programs (Sollero et al., 2011). Despite their importance, no information about Piau blastocyst characteristics can be found in the literature. Thus, we aimed to characterize the membrane fatty acid composition because this information is important for successful cryopreservation. Subsequently, we investigated the response of those embryos to the vitrification and warming process.

The plasma membrane composition is a tool for understanding the kinetics of the entrance of water and cryoprotectants into the cell during vitrification and warming (Dunning et al., 2014; Leao et al., 2015; Nguyen et al., 2016). This phospholipid profile has already been well characterized for bovine oocytes (Spricigo et al., 2015) and embryos (Sudano et al., 2012; Leao et $a l ., 2015)$, ovine oocytes and embryos (Ferreira et al., 2010), and human oocytes (Ferreira et al., 2010). However, the present study describes, for the first time, the membrane phospholipid composition of porcine blastocysts. The significance of that information relies on the observation that when the proportion of short carbon chains and polyunsaturated phospholipid is high, the membrane permeability is also high, reducing the osmotic toxicity during cryopreservation and warming (Seidel, 2006).

In the MALDI-TOF analyses, 16 lipids were identified. Among the phospholipids, phosphatidylcholine [PC $(32: 0)+\mathrm{H}]+$; [PC $(34: 1)+\mathrm{H}]+$ and $[\mathrm{PC}(36: 4)+\mathrm{H}]+$, represented by $734.5,760.5$ and $782.5 \mathrm{~m} / z$ ions, respectively, showed the highest intensity in most evaluated blastocysts. These phospholipids are described in several mammal species (Ferreira et al., 2010). In addition to the identified phospholipids, MALDI-TOF analysis also pointed out some triglycerides (TG), including PPL (50:2) + $\mathrm{Na}+$, PPO $(50: 1)+\mathrm{Na}+$, PLO $(52: 3)+\mathrm{Na}+$ and POO 
$(52: 2)+\mathrm{Na}+$, which are represented by 853.5 , $855.7,879.7$ and $881.6 \mathrm{~m} / \mathrm{z}$ ions, respectively. It is difficult to understand how this fatty acid composition affects the cell physiology, but in comparing our results to the MALDI spectrums previously published (Ferreira et al., 2010), it can be assumed that the phospholipid profile in this study is very similar to that for bovine blastocysts, which have an acceptable resistance to cryopreservation (Oliveira Leme et al., 2016). This information might indicate that membrane phospholipids are not the major problem affecting the cryopreservation of pig embryos. However, the presence of several triglycerides identified here in pig embryos is more similar to the profile reported for bovine oocytes than that reported for bovine embryos. It is well established that bovine oocytes have the highest TG content (Dunning et al., 2014) and face several cryopreservation challenges (Spricigo et al., 2015). In agreement with other authors (Polge and Willadsen, 1978; Nagashima et al., 1995; Ren et al., 2015), our results suggest that the embryo TG content may be one of the factors responsible for porcine embryo cryopreservation failure. During vitrification and warming, the high TG content possibly induces the overproduction of reactive oxygen species (ROS) and hydrogen peroxide $\left(\mathrm{H}_{2} \mathrm{O}_{2}\right)($ Ren et al., 2015). ROS may be involved in the process of apoptosis beyond causing cell membrane damage (Giaretta et al., 2013). Even though we have no data to support these ideas, they are important to evaluate in further studies on porcine embryo cryopreservation.

Subsequently, the resistance of Piau blastocysts to cryopreservation was tested. One possible option for cryopreservation of porcine embryos would be the slow freezing (Nagashima et al., 1992). However, this methodology exposes the embryo to even higher ROS production compared to vitrification methodologies, inducing the oxidation of the double bonds within the carbon chain in unsaturated fatty acids of TG (Mandawala et al., 2016). Vitrification and, more specifically, the Cryotop method have been proposed as a more successful approach for embryo cryopreservation for many mammalian species Kuwayama et al., 2005a; Kuwayama, et al., 2005b; Vajta and Kuwayama, 2006). This procedure has the advantage of not forming ice crystals and has a high cooling speed (Vajta et al., 1998). We compared fresh and vitrified/ warmed in vivo Piau blastocysts, evaluating the re-expansion and hatching rates at 24 and 48 hours of in vitro culture. As expected, fresh blastocysts had a higher hatching rate at 24 and 48 hours (67.7 and 97.6\%) compared to vitrified embryos (15.4 and 36.0\%). Previous studies from Ushijima et al. (2004) and Sakagami et al. (2016) described similar hatching rates at 48 hours after warming ( $\cong 50 \%$ ) using Cryotop and Solid Surface, respectively. One possible reason for the difference between our results and those cited above could be that, instead of using porcine blastocyst medium (PBM, IFP; (Mito et al., 2012)) for in vitro culture, we used bovine SOF medium (Holm et al., 1999). In another study, Cuello et al. (2004) observed hatching rates of $70 \% 96$ hours after vitrification and warming. Despite low hatching rates observed in our experiment, the survival rates of vitrified blastocyst $(48.1 \%)$ were comparable to others described in the literature $(53.0 \%)$ (Mito et al., 2015). In the present study, we only observed samples until 48 hours after warming; if these blastocysts had stayed longer in SOF, the hatching would likely be higher. However, the blastocysts were vitrified at D6, and thus prolonging the time in culture to more than 48 hours would not measure the embryo viability because the embryos might have hatched by then.

Although the best parameter to assess embryo competence after cryopreservation would be the pregnancy rate (Mito et al., 2015; Martinez et al., 2016), the survival rates and the capacity developed further in vitro can be used as predictors for embryo resistance after cryopreservation. The present study has shown that vitrification is a valid tool for cryopreserving porcine blastocysts because it allows for the blastocyst to be rehydrated and develop to further stages, including hatching after warming. This was the first time that such a technique was employed for a South American porcine breed.

Finally, expression of apoptotic related genes was observed after 48 hours of in vitro culture in fresh and vitrified/warmed blastocyst. Apoptosis is a dynamic process that is recurrently cited in several mammalian cell types and species (Giaretta et al., 2013; Spricigo et al., 2017). It is one of the possible pathways responsible for the loss of viability after cryopreservation (Morato et al., 2010; Castillo-Martin et al., 2015). Among 
the evaluated genes, only BAX was significantly affected; it was upregulated in the vitrificated and warmed group. This gene is a member of the BCL2 super family, which is a group of regulatory proteins involved in apoptosis. This family consists of proapoptotic proteins (such as $\mathrm{BAX}$ and BAK) that accumulate in the outer membrane of mitochondria and interact with antiapoptotic proteins (such as BCL2L1). This results in the release of cytochrome $\mathrm{C}$ and leads to apoptosis via the intrinsic pathway (Finucane et al., 1999). The observed nearly 2-fold overexpression of BAX mRNA in vitrified/warmed blastocyst may indicate that the initial phase of apoptosis had begun. After the death signal (BAX), BCL2L1, which is an antiapoptotic molecule, is often translocated to the mitochondria, where pro-apoptotic molecules already reside. This cell mechanism is an attempt to inhibit the activation of these pro-apoptotic molecules (Finucane et al., 1999). However, it was not possible to observe alteration in BCL2L1 transcript abundance at 48 hours. Similar findings are described after vitrification of bovine (Anchamparuthy et al., 2010) and canine (Turathum et al., 2010) oocytes; in both species, upregulation of BAX expression (but not of BCL2L1 expression) was described. Therefore, we may speculate that apoptosis occurred in the very beginning and that this pathway may not be the most important in determining blastocyst degeneration during cryopreservation.

\section{CONCLUSIONS}

In conclusion, we have characterized the main phospholipids present in the plasma membrane of Piau embryos. We also found significant levels of some triglycerides in those embryos. Finally, we have demonstrated that vitrification by Cryotop methodology can be used for the cryopreservation of such embryos.

\section{REFERENCES}

ANCHAMPARUTHY, V.M.; PEARSON, R. E.; GWAZDAUSKAS, F.C. Expression pattern of apoptotic genes in vitrified-thawed bovine oocytes. Reprod. Domest. Anim., v.45, p.e83e90, 2010.
CASTILLO-MARTIN, M.; YESTE, M.; PERICUESTA, E. et al. Effects of vitrification on the expression of pluripotency, apoptotic and stress genes in in vitro-produced porcine blastocysts. Reprod. Fertil. Dev., v.27, p.10721081, 2015.

CASTILLO-MARTIN, M., BONET, S.; MORATÓ R.; YESTE, M. et al. Supplementing culture and vitrification-warming media with 1ascorbic acid enhances survival rates and redox status of IVP porcine blastocysts via induction of GPX1 and SOD1 expression. Cryobiology, v.68, p.451-458, 2014.

CUELLO, C.; GIL, M.A.; PARRILLA, I. et al. In vitro development following one-step dilution of OPS-vitrified porcine blastocysts. Theriogenology, v.62, p.1144-1152, 2004.

DAVOLI, R.; BRAGLIA, S. Molecular approaches in pig breeding to improve meat quality. Brief Funct Genomic Proteomic, v.6, p.313-321, 2007.

DIAZ, F. et al. Cryopreservation of day 8 equine embryos after blastocyst micromanipulation and vitrification. Theriogenology, v.85, p.894-903, 2016.

DUNNING, K.R.; RUSSELL, D.L.; ROBKER, R.L. Lipids and oocyte developmental competence: the role of fatty acids and betaoxidation. Reproduction, v.148, p.R15-R27, 2014.

FAO statistical database 2009. Roma: FAO, 2009.

FERREIRA, C.R.; SARAIVA, S.A.; CATHARINO, R.R. et al. Single embryo and oocyte lipid fingerprinting by mass spectrometry. J. Lipid Res., v.51, p.1218-1227, 2010.

1. FINUCANE, D.M.; BOSSY-WETZEL, E.; WATERHOUSE, N.J. et al. Bax-induced caspase activation and apoptosis via cytochrome c release from mitochondria is inhibitable by Bcl-xL. J. Biol. Chem., v.274, p.2225-2233, 1999.

FRANÇA, L.R. Analise morfofuncional da espermatogênesede suínos adultos da raça Piau. 1991. 185f. Dissertação (Mestrado em Morfologia). Instituto de Ciências Biológicas Universidade Federal de Minas Gerais, Belo Horizonte, MG. 
GARCIA-GARCIA， R.M. DOMINGUEZ, V. VEIGA-LOPEZ, A. et al. Culture of early stage ovine embryos to blastocyst enhances survival rate after cryopreservation. Theriogenology, v.63, p.2233-2242, 2005.

GIARETTA, E.; SPINACI, M.; BUCCI, D. et al. Effects of resveratrol on vitrified porcine oocytes. Oxid. Med. Cell. Longev., v.2013, p.920257, 2013.

GILBERT, M.; CONCHEDDA, G.; BOECKEL, T.P.V. et al. Income disparities and the global distribution of intensively farmed chicken and pigs. PLoS One, v.10, p.e0133381, 2015.

HOLM, P.; BOOTH, P.J.; SCHMIDT, M.H. et al. High bovine blastocyst development in a static in vitro production system using SOFaa medium supplemented with sodium citrate and myo-inositol with or without serum-proteins. Theriogenology, v.52, p.683-700, 1999.

KUWAYAMA, M.; VAJTA' G. IEDA, S. et al. Comparison of open and closed methods for vitrification of human embryos and the elimination of potential contamination. Reprod. Biomed., v.11, p.608-614, 2005a.

KUWAYAMA, M.; VAJTA, G.; KATO, O. et al. Highly efficient vitrification method for cryopreservation of human oocytes. Reprod. Biomed., v.11, p. 300-308, 2005b.

LEAO, B.C.; ROCHA-FRIGONI, N.A.; CABRAL, E.C. et al. Membrane lipid profile monitored by mass spectrometry detected differences between fresh and vitrified in vitroproduced bovine embryos. Zygote, v.23, p.732$741,2015$.

MANDAWALA, A.A.; HARVEY, S.C.; ROY, T.K.; FOWLER, K.E. Cryopreservation of animal oocytes and embryos: current progress and future prospects. Theriogenology, v.86, p.1637-1644, 2016.

MARTINEZ, E.A.; CUELLO, C.; PARRILLA, I. et al. Recent advances toward the practical application of embryo transfer in pigs. Theriogenology, v.85, p.152-161, 2016.

MITO, T.; YOSHIOKA, K.; NOGUCHI, M. et al. Birth of piglets from in vitro-produced porcine blastocysts vitrified and warmed in a chemically defined medium. Theriogenology, v.84, p.1314-1320, 2015.
MITO, T.; YOSHIOKA, K.; YAMASHITA, S. et al. Glucose and glycine synergistically enhance the in vitro development of porcine blastocysts in a chemically defined medium. Reprod. Fertil. Dev., v.24, p.443-450, 2012.

MORATO, R.; IZQUIERDO, D.; PARAMIO, M.T.; MOGAS, T. Survival and apoptosis rates after vitrification in cryotop devices of in vitroproduced calf and cow blastocysts at different developmental stages. Reprod. Fertil. Dev., v.22, p.1141-1147, 2010 .

NAGASHIMA, H.; KASHIWAZAKI, N.; ASHMAN, R.J. et al. Cryopreservation of porcine embryos. Nature, v.374, p.416, 1995.

NAGASHIMA, H.; YAMAKAWA, H.; NIEMANN, H. Freezability of porcine blastocysts at different peri-hatching stages. Theriogenology, v.37, p.839-850, 1992.

NGUYEN, V.H.; NGUYEN, V.L.; HOANG, N.S.; DO, T.K. Effect of cell membrane permeability protein on porcine oocyte vitrification. Cryo Lett., v.37, p.103-109, 2016.

NIEDERMEYER, T. H.; STROHALM, M. mMass as a software tool for the annotation of cyclic peptide tandem mass spectra. PLoS One, v.7, p.e44913, 2012.

OLIVEIRA LEME, L.; DUFORT, I.; SPRICIGO, J.F.W. et al. Effect of vitrification using the Cryotop method on the gene expression profile of in vitro-produced bovine embryos. Theriogenology, v.85, p.724-733 e1, 2016.

PFAFFL, M.W. A new mathematical model for relative quantification in real-time RT-PCR. Nucl. Acids Res., v.29, p.e45, 2001.

POLGE, C.; WILLADSEN, S.M. Freezing eggs and embryos of farm animals. Cryobiology, v.15, p.370-373, 1978.

REN, L.; FU, B.; MA, H.; LIU, D. Effects of mechanical delipation in porcine oocytes on mitochondrial distribution, ROS activity and viability after vitrification. Cryo Lett., v.36, p.3036, 2015.

ROBERTSON, I.N.R. Certification and identification of the embryo. In: STRINGFELLOW, D.; SEIDEL, S.M. (Eds.). Manual of the international embryo transfer society. [USA]: Savoy, 1998. p.103-134. 
SAKAGAMI, N.; NISHIDA, K.; MISUMI, K. et al. The relationship between oxygen consumption rate and viability of in vivo-derived pig embryos vitrified by the micro volume air cooling method. Anim. Reprod. Sci., v.164, p.4046, 2016.

SARAGUSTY, J.; ARAV, A. Current progress in oocyte and embryo cryopreservation by slow freezing and vitrification. Reproduction, v.141, p.1-19, 2011.

SEIDEL JÚNIOR, G.E. Modifying oocytes and embryos to improve their cryopreservation. Theriogenology, v.65, p.228-235, 2006.

SOLLERO, B.P. PAIVA, S.R.; FARIA, D.A. et al. Genetic diversity of Brazilian pig breeds evidenced by microsatellite markers. Livest. Sci., v.123, p.8-15, 2009.

SOLLERO, B.P. GUIMARÃES, S.E.; RILINGTON, V.D. et al. Transcriptional profiling during foetal skeletal muscle development of Piau and Yorkshire-Landrace cross-bred pigs. Anim. Genet., v.42, p.600-612, 2011.

SPRICIGO, J.F. MORATÓ, R.; ARCARONS, N. et al. Assessment of the effect of adding Lcarnitine and/or resveratrol to maturation medium before vitrification on in vitro-matured calf oocytes. Theriogenology, v.89, p.47-57, 2017.

SPRICIGO, J.F. DIÓGENES, M.N.; LEME, L.O. et al. Effects of different maturation systems on bovine oocyte quality, plasma membrane phospholipid composition and resistance to vitrification and warming. PLoS One, v.10, p.e0130164, 2015.
SUDANO, M.J. SANTOS, V.G.; TATA, A. et al. Phosphatidylcholine and sphingomyelin profiles vary in Bos taurus indicus and Bos taurus taurus in vitro- and in vivo-produced blastocysts. Biol. Reprod., v.87, p.130, 2012.

TURATHUM, B. SAIKHUN K.; SANGSUWAN, P. et al. Effects of vitrification on nuclear maturation, ultrastructural changes and gene expression of canine oocytes. Reprod. Biol. Endocrinol., v.8, p.70, 2010.

USHIJIMA, H. YOSHIOKA, H.; ESAKI, R. et al. Improved survival of vitrified in vivo-derived porcine embryos. J. Reprod. Dev., v.50, p.481486, 2004.

VAJTA, G. HOLM, P.; KUWAYAMA, M. et al. Open Pulled Straw (OPS) vitrification: a new way to reduce cryoinjuries of bovine ova and embryos. Mol. Reprod. Dev., v.51, p.53-58, 1998.

VAJTA, G.; KUWAYAMA, M. Improving cryopreservation systems. Theriogenology, v.65, p.236-244, 2006.

VANDESOMPELE, J. De PRETER, K.; PATTYN, F, et al. Accurate normalization of real-time quantitative RT-PCR data by geometric averaging of multiple internal control genes. Genome Biol., v.3, p.34, 2002. 